\title{
ARTUR RÓŻAŃSKI
}

\section{Czeskie i morawskie wzorce architektoniczne na terenie ziem polskich we wczesnym średniowieczu. Fakty i mity}

\section{Czech and Moravisn architectonic patterns in the area of Polish grounds in early Middle Ages. Facts and myths}

Związki między państwami Piastów a Przemyślidów we wczesnym średniowieczu stanowią bez wątpienia jeden z ciekawszych aspektów szeroko rozumianych dziejów tych dwóch graniczących ze sobą państw ${ }^{1}$. Dość powszechnie panujący w literaturze pogląd o ścisłej zależności między architekturą polską a tą powstałą w państwach czeskim czy wielkomorawskim powstał w dużej mierze na kanwie odkryć archeologicznych mających miejsce w początkach XX wieku. Odkrycia te stały się przyczynkiem do poszukiwań zbieżności architektonicznych, głównie przez formy rotund prostych. Niekontrolowanym tworem tych dociekań jest narosły od lat i coraz obszerniejszy stan badań, powstały na bazie dociekań zarówno historyków, historyków sztuki, jak i archeologów.

Zalążkiem wszystkiego i niewątpliwie najistotniejszym wydarzeniem w związkach polsko-czeskich w okresie wczesnośredniowiecznym stał się ślub Mieszka I i córki księcia czeskiego Bolesława I Srogiego - Dobrawy. Związek zawarty między Piastem a Przemyślidką symbolicznie legł u podstawy dzisiejszych dociekań na temat źródeł wczesnopiastowskiej architektury, wysnuwanych często na zasadzie analogii. Dobrawie przypisuje się bowiem szereg zasług na polu wprowadzenia chrześcijaństwa na teren pogańskich Polan, w jej otoczeniu zaś chętnie szuka się właściwych twórców polskiego Kościoła. Warto zatem zastanowić się, czy powiązania polityczno-rodzinne i religijne przełożyły się na związki artystyczne. Należy również przypomnieć, że nie tylko związki dynastyczne były ważne w postrzeganiu polsko-czesko-morawskiej wspólnoty architektonicznej.

\footnotetext{
${ }^{1} \mathrm{~W}$ ostatnich czasach możemy obserwować pewien nawrót zainteresowania naszymi południowymi sąsiadami i wzajemnymi powiązaniami z państwem polskim (Przemyślidzi i Piastowie 2006).
} 
Nie mniej istotny wkład miała dobrze znana wzmianka pochodząca z Żywota św. Metodego, mówiąca o księciu pogańskim, silnym bardzo, siedzącym w Wiślech, który urągał chrześcijanom i krzywdy im wyrządzał. Według powszechnej wiedzy historyków i archeologów wspomniany książę zasiadał w Wiślicy (Gąssowski 1997, s. 13-19). Późniejsze odkrycia archeologiczne w pełni potwierdziły hipotezę badaczy, a odsłonięty zespół budowli miał bez cienia wątpliwości świadczyć o istnieniu na tym terenie stolicy księcia wiślańskiego (Dobosz 2002). Jak się okazało, żadna z nich nie była tą, za jaką pierwotnie ją uważano, by przytoczyć choćby zdanie Andrzeja Tomaszewskiego, uczestnika badań wiślickich. Badacz ten, odnosząc się do tzw. misy chrzcielnej oraz zlokalizowanego przy niej ,podium” stwierdził, że mamy tutaj do czynienia ,z dwoma tworami, których forma, będąca podstawą wszelkich pomysłów interpretacyjnych, nie jest pierwotna i nie odpowiada prawdzie" (Tomaszewski 1997, s. VII; Rodzińska-Chorąży 1998, s. 561-572).

Niniejszy artykuł nie prezentuje pełnej historii badań nad interesującym mnie zagadnieniem, ani też rozważań nad wszystkimi elementami możliwych związków architektury polskiej z czeską czy wielkomorawską. Jego celem jest jedynie przedstawienie najważniejszych kwestii poruszanych w literaturze przedmiotu, a także wskazanie na zagadnienia, które nie doczekały się pełnej analizy.

Jak trafnie przed kilkoma laty zauważył Zygmunt Świechowski, poglądy na temat początków architektury sakralnej na ziemiach polskich skupiają się wokół dwóch zasadniczych nurtów. Pierwszy to tzw. opcja wielkopolska zakładająca, że pierwsze obiekty murowane mogły powstać dopiero po 966 roku, po chrzcie Polski. Drugi to tzw. opcja czeska, przyjmująca, że proces chrystianizacji ziem południowej Polski znacznie wyprzedził tzw. Chrzest Polski, który ograniczony był w rzeczywistości tylko do terenu Wielkopolski (Świechowski 2003, s. 133). Warto zauważyć, że podejście do chronologii wczesnej architektury również ma charakter dwubiegunowy. Badacze wielkopolscy skłonni są często do postarzania budowli, zakładając istnienie jakiegoś wielkopolskiego matecznika przedromańskiej architektury, natomiast wśród badaczy małopolskich funkcjonuje skłonność do ich odmładzania.

Motywacja do tego typu działań w każdym przypadku wydaje się krańcowo różna. Zapewne wśród niektórych badaczy małopolskich rodzi się lęk, że potwierdzą się morawsko-czeskie korzenie niektórych budowli, co jest o tyle dziwne, że wybitni krakowscy historycy sztuki już przed wybuchem drugiej wojny światowej odnosili wczesne budowle murowane Wawelu do okresu czeskich rządów w Krakowie, nie bacząc na opozycję wpływowych historyków - Tadeusza Dobrowolskiego (1974, s. 25) i Wojsława Mole (1932/1933, s. 23-30), a także młodszego od nich historyka architektury Adama Miłobędzkiego (1998). W ostatniej tercji minionego stulecia role się odwróciły. W miarę postępu badań na osadnictwem Małopolski stało się niemal oczywiste, że - jak piszą Zofia i Stanisław Kurnatowscy - „główne impulsy kulturowe dochodzą na te ziemie z południa”, a odmienność kulturowa 
ziem południowej Polski uwidacznia się szczególnie w budownictwie nawiązującym do terenów morawsko-czeskich (Kurnatowska, Kurnatowski 2003, s. 169). Z kolei Janusz Firlet i Zbigniew Pianowski, ustosunkowując się do urbanistycznego układu Wawelu uznali, że „najbliższą a zarazem najpełniejszą analogię pod względem architektoniczno-funkcjonalnym dla Wawelu stanowią Gród Praski oraz Wyszechrad" (Firlet, Pianowski 2006, s. 55). Podobnie Jerzy Wyrozumski uwzględniając przekazy źródłowe oraz rezultaty badań archeologiczno-architektonicznych wawelskiego wzgórza stwierdził, ,że przynajmniej niektóre z [...] budowli sakralnych musiały powstać pod panowaniem czeskim, a to oznacza, że w ówczesnej monarchii Przemyślidów Kraków, choć peryferyjnie położony, zajmował ważne miejsce" (Wyrozumski 2006, s. 45).

Choć, jak się wydaje, brakuje przesłanek do suponowania możliwości istnienia na terenach ziem polskich zorganizowanych form obrządku słowiańskiego, to co pewien czas możemy obserwować nawroty do koncepcji zakładającej powodzenie, hipotetycznej wciąż, małopolskiej misji Cyryla i Metodego. Jak twierdzi Edmund Małachowicz „od dawna wiadomo, że chrystianizacja w obrządku łacińskim dotarła do Polski ze strony Czech, ale od niedawna ukazały się dowody, że podobnie jak w Czechach poprzedził ją obrządek słowiański, tj. cyrylo-metodiański”" (Małachowicz 2010, s. 56). Zdaniem tego badacza rozpoczęta na Morawach w 863 roku misja dotarła do Czech około 883 roku, w podobnym czasie miała też objąć tereny południowych ziem późniejszego państwa polskiego, tj. Śląska i ziemi krakowskiej. W świetle badań E. Małachowicza ślady omawianej misji na Śląsku można datować na lata 90. IX wieku, a być może nieco wcześniej w Krakowie. Na Śląsku ów obrządek miał przetrwać do końca X wieku, między innymi w Niemczy. Warto w tym miejscu zastanowić się, na jakich to „niezbitych dowodach” ów badacz opiera swoje spostrzeżenia, bowiem jak przedstawia „relikty murów fundamentowych pierwszej z nich [katedr - A. R.] zachowane pod trzema kolejnymi budowlami późniejszymi, tylko w niewielkich odcinkach w trzech węzłowych partiach, pozwoliły na hipotetyczną rekonstrukcję planu, w pełni potwierdzoną przy pomocy georadaru, jako budowlę na planie krzyża" (Małachowicz 2010, s. 58). W tym miejscu, jako archeolog, badacz i miłośnik architektury, a także obserwator efektów prac przy użyciu georadaru (Poznań-Ostrów Tumski, Gołańcz, Opalenica), z czystym sumieniem powinienem zakończyć omawianie efektów badań tego typu nad obiektami sakralnymi pochodzącymi z czasów misji słowiańskiej na Śląsku. Cóż jednak począć?, skoro autor kieruje się maksymą Alberta Einsteina - „Wyobraźnia jest ważniejsza od wiedzy" (Małachowicz 2009, s. 67).

Warto wskazać, na jak kruchych podstawach budowana jest wiedza o wspomnianych świątyniach. Nieco światła na zastosowaną przez odkrywcę kościołów metodę mogą rzucić dane liczbowe. $\mathrm{Z}$ opracowania badań archeologicznych autorstwa Józefa Kaźmierczyka, na które, nota bene, powołuje się E. Małachowicz, wynika, że strop calca rysował się na głębokości 5-6 m poniżej dzisiejszego poziomu gruntu, 
przy czym należy pamiętać, że teren przykatedralny znajdował się na niewielkim wypiętrzeniu i tutaj calec zalegał na głębokości 4,2-4,7m (Kaźmierczyk 1991, s. 16). Dla łatwiejszego zobrazowania warto wspomnieć, że wartość $115,40 \mathrm{~m}$ jest wyznacznikiem wody gruntowej, na tym też poziomie oparto najniższe warstwy wałowe grodu wrocławskiego (Kaźmierczyk 1991, ryc. 19). Badania archeologiczne wykazały, że poniżej tego poziomu nie odnotowano żadnych śladów działalności człowieka. Jak zatem przedstawia się konfrontacja interpretacji danych z georadaru $\mathrm{z}$ danymi pochodzącymi z badań archeologicznych? Jak przedstawiają się ustalenia E. Małachowicza, opierającego się na danych pochodzących z badań archeologicznych oraz na badaniach własnych? Przykładem jest rycina zamieszczona w kilku, ostatnio opublikowanych, artykułach tego autora (Małachowicz 2009, s. 85; 2010, s. 62). Na przekroju przez fundamenty, odkryte w południowej nawie katedry, oznaczono wartości zalegania poszczególnych obiektów sakralnych. Stamtąd możemy dowiedzieć się, że eksplorację tradycyjnymi metodami zakończono na 4,47 m poniżej poziomu dzisiejszej posadzki katedry, i to na tym niemalże poziomie zalegały relikty tzw. I katedry datowanej na około 965 rok. Rozważając przedstawione wyżej dane należy założyć, że fundamenty tej budowli wkopane były już w znajdujący się niewiele niżej calec. Na analizowanej rycinie podano wartość $6 \mathrm{~m}$, na której zalegał poziom osadniczy w $\mathrm{X}$ wieku, co w świetle przedstawionych wyżej danych nie do końca odpowiada faktycznemu stanowi. Z uwagi na to, że sprawą „katedr” zajmowali się niedawno Paweł Rzeźnik i Adam Żurek, na potrzeby podejmowania tego tematu (Rzeźnik, Żurek 2001, s. 335-352). Warto jednak poświęcić uwagę kolejnemu kościołowi pochodzącemu, zdaniem odkrywcy, E. Małachowicza, z około 915 roku, co musi budzić wiele zastrzeżeń. Po pierwsze trudne do akceptacji są wskazane przez niego rzędne osadnictwa z X wieku. Jak wyżej podano najniższy poziom jakiegokolwiek osadnictwa rysuje się na głębokości 4,2-4,7 m (Kaźmierczyk 1991, s. 16), a nie 6 m jak przyjmuje wspomniany badacz. Musi zatem dziwić interpretacja anomalii występujących w odczycie danych z georadaru na poziomie $7 \mathrm{~m}$ jako pozostałości pierwszej wrocławskiej świątyni. Wszak sam autor stawia znak zapytania przy odniesieniu do gruntu nośnego. Zdałoby się w tym miejscu przypomnieć poziom wód gruntowych wynoszący $115,40 \mathrm{~m}$, podczas gdy omawiany relikt miałby znajdować się na poziomie $113,42 \mathrm{~m}$, czyli $2 \mathrm{~m}$ poniżej lustra wody(!). Zatem nic dziwnego, że E. Małachowicz taki nacisk kładzie na wyobraźnię, skoro jak twierdzi J. Kaźmierczyk „wobec braku dowodów, a nawet przesłanek do rekonstrukcji grodu wrocławskiego, uderza bogactwem szczegółów jego bryła przedstawiona w książce E. Małachowicza. Szczegóły te są nieznane z wałów wrocławskich, uderzające podobieństwo wykazują natomiast z odkrytym niedawno reliktem wału w Legnicy" (Kaźmierczyk 1991, s. 45, przypis 39).

Kolejny kościół mający pochodzić z czasów tzw. misji cyrylo-metodiańskej to również „twór georadaru”. Mowa w tym miejscu o obiekcie w Niemczy, gdzie w trakcie przeprowadzonych badań w latach 60 . XX wieku odkryto „regularny 
układ kamieni na zaprawie z gliny", który został określony jak fragment starszej budowli, datowanej na podstawie otaczającej ją warstwy kulturowej na IX-X wiek (Hołbowicz 1960, s. 39). Przeprowadzone w 2007 roku badania georadarowe ukazały zarys kościoła w całości mieszczącego się we wnętrzu XIV-wiecznej budowli przebadanej w 1960 roku. „Zrekonstruowany plan budowli wraz z ołtarzem w formie prostokątnej nawy i takiegoż mniejszego chóru podobny do kościołów morawskich z IX-X wieku" (Małachowicz 2010, s. 58). Warunkowo zawierzył takiej interpretacji Z. Świechowski w swoim najnowszym katalogu architektury romańskiej, wskazując na dość szeroko zakreślony horyzont czasowy mieszczący się od X do XI wieku ze względu na użycie w fundamentach płytowego kamienia łamanego (Świechowski 2009, s. 324).

Ostatnim z obiektów ufundowanych od końca IX do końca 2. dekady X wieku jest dwuapsydowa rotunda wzniesiona na górze Gromnik, porównywana z kościołami w Mikulčicach czy wawelskim kościołem „B”. Jednak datowanie tego obiektu nie jest tak jednoznaczne jak chciałby tego E. Małachowicz. Zdaniem Krzysztofa Jaworskiego prowadzącego badania archeologiczne na Gromniku do kwestii chronologii „należy odnosić się z dużą rezerwą, zarówno do upatrywania w rotundzie najstarszej polskiej świątyni, jak i do jednoznacznego, bezkrytycznego datowania tego archaicznego tworu o skomplikowanej stratygrafii wyłącznie na wiek XV" (Jaworski, Pankiewicz 2007, s. 102). W świetle powyższego trudno zgodzić się z E. Małachowiczem, że otrzymaliśmy pewne dowody istnienia obrządku cyrylo-metodiańskiego na ziemiach polskich. Zatem może trafniejszym mottem dla poczynań tego badacza mogłyby się stać słowa Adama Mickiewicza z ballady „Romantyczność”: „Czucie i wiara silniej mówią do mnie niż mędrca szkiełko i oko", aniżeli przytaczane przez niego samego słowa Alberta Einsteina.

Jednym z ciekawszych zagadnień dotyczących ewentualnych wpływów czy zapożyczeń z rozwiązań architektury czeskiej jest zagadkowa i nierozwiązana do tej pory kwestia portalików znajdujących się na poziomie empory zachodniej. W nauce czeskiej od czasów Martina Kolářa utrwalił się pogląd o powiązaniu owych portalików z piętrem nieopodal znajdującego się pałacu/dworu (Koláŕ 1876, s. 250). Tym samym ugruntowana została hipoteza dotycząca funkcji jednonawowych kościołów z emporami i ich przestrzennego usytuowania względem siedziby władcy. Późniejsze badania Vojtěcha Birnbauma (1929) miały jednoznacznie potwierdzić ten stan wiedzy. Zdaniem tego badacza „o naszych własnych kościołach emporowych [...] w Potvorovie i we Vroutku, sądzi Neuwirth, że ich empory były połączone z sąsiadującymi grodami, przez co przynajmniej wskazuje, iż były one zastrzeżone dla państwa". Josef Braniš natomiast powiada wprost, że empora była przeznaczona dla dostojniejszych osób, a o emporach w Potvorovie i Vinci orzeka również, że się na nie wchodziło portalikiem w pierwszym piętrze, wprost z sąsiadującej warowni. Podobnie sądzi o tetińskim kościele Ferdinand Lehner, który jednak $\mathrm{w}$ innych przypadkach, gdzie też wiedzie na emporę portalik wprost z zewnątrz 
w pierwszym piętrze (Chřenowice, Portoltice, Milevsko - św. Idzi), domyśla się, że ku portalikowi wstępowało się z ziemi po drewnianych schodach (Tomaszewski 1974, s. 21). Kolejnym badaczem, który podjął się trudu rozwiązania problemu empor był Václav Mencl. Przeanalizował on kościoły znajdujące się na terenach słowackich, a wyniki tych badań, jakby się mogło wydawać, nieco osłabiły tezy V. Birnbauma. Analiza wykazała, że kościoły słowackie w odróżnieniu od czeskich nie posiadają górnych wejść na emporę, bowiem połączone są z kościołem od wnętrza świątyni (Mencl 1937, s. 125). Jednakże podstawową pracą na temat opisywanego tu zagadnienia jest inne opracowanie V. Mencla, będące pełną analizą zagadnienia (Mencl 1965, s. 29-62). Pomimo upływu już niemal półwiecza stanowi ono jedyne tego rodzaju opracowanie, w którym jednak autor nie uchronił się od kilku błędów i pewnego rodzaju uproszczeń. Václav Mencl wyizolował czeski materiał źródłowy od tego pochodzącego z sąsiadujących krajów środkowo-wschodniej Europy, co w konsekwencji doprowadziło do jednostronnych wniosków, które dziś moglibyśmy określić mianem swoistego case study. Z uwagi na brak lub znikomą ilość kompleksowych badań archeologicznych przy niewielkich obiektach architektury sakralnej, w ogromnej większości sądy V. Mencla pozostają nieweryfikowalne. Dopiero w ostatnich latach obserwowany jest na terenach naszych południowych sąsiadów wzrost zainteresowania tego typu obiektami (Sommer 2001; Klápště 2010, s. 217-227; Boháčová 2010, s. 190-198). Należy się jednak zastanowić, czy badania archeologiczne zmieniały, a przede wszystkim, czy miały szanse zmienić postrzeganie analizowanych tutaj obiektów. Klinicznym przykładem jest opracowanie romańskiego kościoła św. Marcina w Radomyšlu autorstwa Bořivoja Nechvátala (1999). Autor, przedstawiając wyniki badań, rekonstruuje na południowej elewacji kościoła zewnętrzne wejście na poziom empory i prowadzący od niego portalik w stronę jakiejś bliżej nieokreślonej, zrekonstruowanej wieży (ryc. 1) (Nechvátal 1999, s. 186, ryc. 160; Beranová, Lutovský 2009, s. 361, ryc. 405, 406). O ile z analizą architektoniczną należy się zgodzić, to już jakiekolwiek połączenie z inną budowlą budzić musi spore zastrzeżenia, bowiem w miejscu, gdzie miałaby ona stać - jak wynika z planów umiejscowienia wykopów - nigdy nie podjęto badań (sic!). Zaprzepaszczono zatem szansę jednoznacznego rozwiązania tej zagadkowej kwestii. Czy rzeczywiście ta, jakby się wydawało, spójna koncepcja istniejąca w nauce czeskiej ma rację bytu? Jeśli rozpatrywać kościół jako budowlę o charakterze refugialnym, to tego typu rozwiązanie zupełnie przeczy jakiejkolwiek logice dotyczącej obronności. Nietrudno zgodzić się z Marcinem Paukiem, który pisze, że „wszystkie obiekty murowane, kościoły i klasztory odgrywały w średniowieczu istotną rolę militarną. Mogły służyć swemu patronowi i jego rodzinie, jak też i okolicznej ludności jako miejsce schronienia i oporu w przypadku najazdu zewnętrznego lub niepokojów wewnętrznych" (Pauk 2000, s. 205). Doskonałym potwierdzeniem tej funkcji jest dokument wystawiony w 1281 roku w Pradze, w którym został opisany podział przestrzeni kościoła między prepozytem zderavskim a opatem z Plasów w razie 


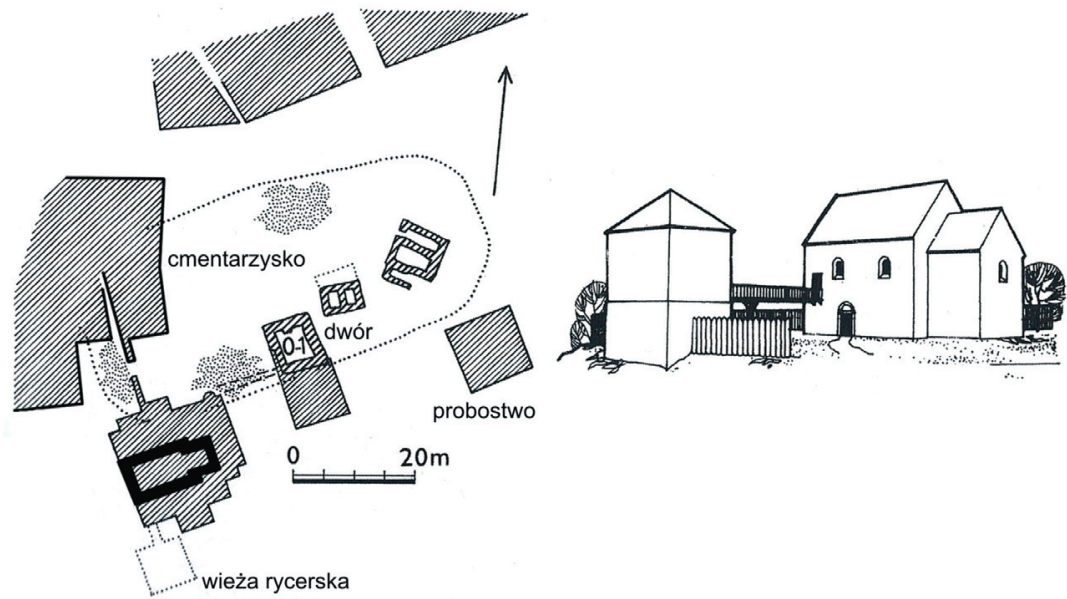

Ryc. 1. Radomyšl, Czechy. Kościół św. Marcina wraz z wieżą rekonstruowaną przez B. Nechvátala (wg Beranová, Lutowský 2009)

Fig. 1. Radomyšl, Czech Republic. St. Martin church with a tower reconstructed by B. Nechvátal (after Beranová, Lutowský 2009)

zagrożenia. Ludność zamieszkująca tereny należące do bożogrobców zderawskich mogła chronić się w nawie kościoła, natomiast in superiori autem parte et turre ipsius ecclesie mogli przebywać tylko ludzie opata z Plasów (Codex 2006, nr 133). Biorąc pod uwagę stosunki własnościowe w przypadku omawianego kościoła jasno pokazano, które miejsce było bezpieczniejsze. To opat - właściciel kościoła - zapewniał sobie względny spokój i poczucie bezpieczeństwa, rezerwując dla siebie i swoich ludzi miejsce na emporze i w wieży. Jak pokazują przykłady czeskie to właśnie w wieży najczęściej znajdowało się wejście na wyższy poziom.

Kościół św. Bartłomieja, ufundowany przez biskupa praskiego Jana około połowy XIII wieku, znajduje się dziś na wschodniej krawędzi aglomeracji praskiej. Świątynia w Kyjach to z pewnością jeden z najlepiej inkastelowanych obiektów na terenie ziem czeskich. Potężna, górująca wieża czyni z niego prawdziwą twierdzę. Zewnętrzne wejście na poziom empory znajduje się na zachodniej elewacji wieży (ryc. 2) (Merhautová 1971, s. 150-152; Benešovská i in. 2001, s. 84-85). Również w wieży umiejscowiono wejście na emporę w kościele św. Piotra w Poříćí nad Sázavou, wzniesionego na początku XII wieku (Merhautová 1971, s. 196; Benešovská i in. 2001, s. 106). Jak wynika z analizy architektonicznej wejście zostało zamurowane dość szybko, może na przełomie XIII i XIV wieku, i zastąpiono je wejściem z poziomu gruntu z zachodniej strony kościoła. Wówczas to wstawiono drewniane schody do wieży na poziom trybuny (ryc. 3). Dość często spotykanym rozwiązaniem na terenie Czech jest umiejscowienie wejścia na ścianie nawy (czasami nawet przy obecności wieży). Jednym z przykładów zastosowania takiego wariantu jest kościół św. Klemensa w Stará Boleslav, niewielki obiekt salowy 


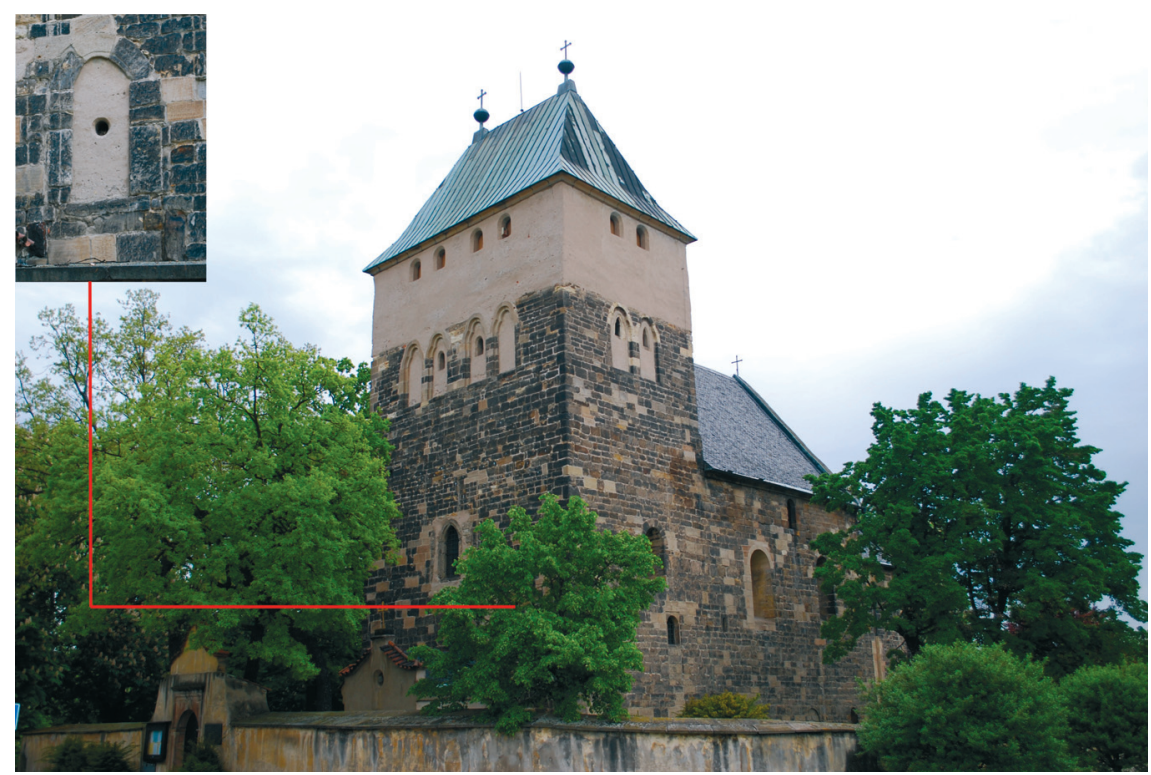

Ryc. 2. Kyje, Czechy. Kościół św. Bartłomieja (fot. A. Różański)

Fig. 2. Kyje, Czech Republic. St. Bartholomew church (photo by A. Różański)

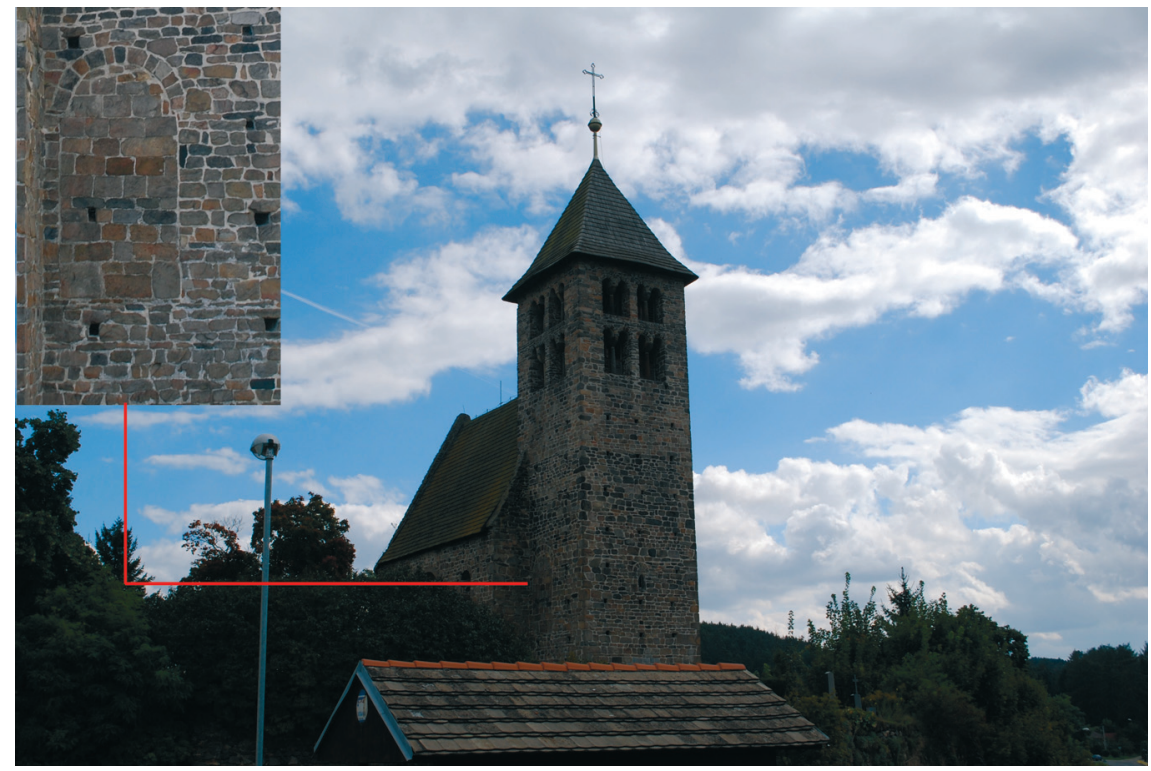

Ryc. 3. Poříčí nad Sázavou, Czechy. Kościół św. Piotra (fot. A. Różański)

Fig. 3. Poříčí nad Sázavou, Czech Republic. St. Peter church (photo by A. Różański) 
zakończony od wschodu apsydą. Od zachodu budowla posiadała drewnianą półkę empory oraz drewniane schody znajdujące się wzdłuż północnej ściany świątyni. Drugie wejście na emporę prowadziło z zewnątrz i znajdowało się na zachodniej ścianie kościoła. Obiekt datowany jest ogólnie na około połowę XII wieku (Tomaszewski 1974, s. 195) lub też, jak dość konkretnie wskazuje V. Mencl, na około 1130 rok (Mencl 1965, s. 34). W katalogu architektury romańskiej z Czech chronologię opisywanego kościoła określono na „wczesny XII wiek”, co jest równoznaczne $\mathrm{z}$ 1. połową tego stulecia, natomiast znajdujące się w apsydzie romańskie freski datowane są na 2. ćwierć XII wieku (ryc. 4) (Benešovská i in. 2001, s. 90-92). Analogiczną emporę posiada kościół św. Gawła w Zbraslaviu, wzniesiony z fundacji książęcej najprawdopodobniej w 1. połowie XII wieku (Tomaszewski 1974, s. 196). Wspomniany obiekt ulegał na przestrzeni wieków licznym przebudowom, zachowując jedynie zachodnią partię świątyni. W północnej ścianie widoczny jest fragment wejścia oraz ślad po arkadowym fryzie (ryc. 5). Niezwykle ciekawy jest także kościół św. Jakuba w miejscowości Rovná (Střibrná Skalice), z wejściem umieszczonym po stronie północnej nawy; świątynia ta również posiadała wieżę. Do dzisiaj przetrwała drewniana belka nadproża wejścia na emporę. W świetle ostatnich badań obiekt datowany jest na „wczesny XII wiek” (Benešovská i in. 2001, s. 104), natomiast około 1180 roku wzbogacono kościół o romańskie freski (ryc. 6, 7) (Merhautová, Třeštik 1983, s. 202-203).

Przedstawione wyżej rozwiązanie przestrzeni kościoła znane jest z terenów ziem polskich tylko w jednym przypadku - z kościoła św. Andrzeja w Kościelcu pod Kołem. W ostatnim czasie świątynia została szeroko omówiona w mojej pracy, zatem pokuszę się tutaj jedynie o przedstawienie najważniejszych ustaleń (Różański 2010, s. 111-160; por. też Różański 2009, s. 525-544). W kościele św. Andrzeja zastosowano niespotykane w XII-wiecznej Polsce rozwiązanie wejścia na emporę z zewnątrz świątyni, znane z terenów czeskich. W świetle dzisiejszego stanu wiedzy trudno jednoznacznie stwierdzić, czy dla kościoła w Kościelcu posiadamy pełną analogię, z uwagi na nie do końca rozwiązaną kwestię istnienia wieży w kościeleckiej świątyni. $Z$ dużą dozą prawdopodobieństwa należy założyć, że mamy tu do czynienia z obiektem bezwieżowym (ryc. 8). Niemalże wszystkie znane przykłady czeskie zbieżne chronologicznie z omawianym obiektem mają W swoim programie przestrzennym wieżę zachodnią. Niezależnie od tego, gdzie znajdowało się wyniesione wejście na emporę zachodnią, jedynym znanym wyjątkiem jest wspomniany wyżej kościół św. Klemensa w Stará Boleslav.

Jak starałem się przedstawić, panujące w nauce czeskiej przekonanie, że zewnętrzne portaliki połączone były przejściem/mostkiem z dworem panującego, niezależnie od tego, czy był nim rycerz, czy też monarcha, trudne jest do przyjęcia z uwagi na brak jednoznacznych źródeł. Nieliczne badania archeologiczne przeprowadzone przy tego typu obiektach nie potwierdzają jednak dość powszechnie przyjętej teorii. Uprzedzając nieco fakty, teoria ta nie znalazła również 


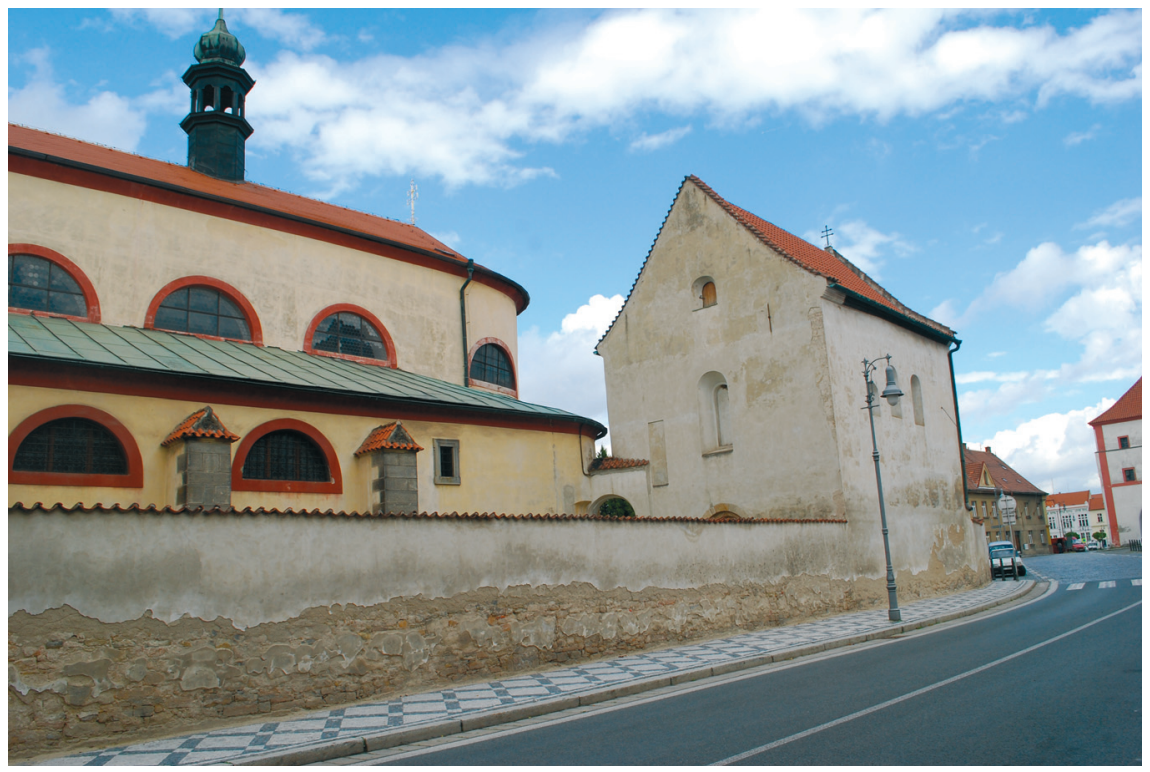

Ryc. 4. Stará Boleslav, Czechy. Kościół św. Klemensa (fot. A. Różański)

Fig. 4. Stará Boleslav, Czech Republic. St. Clement church (photo by A. Różański)

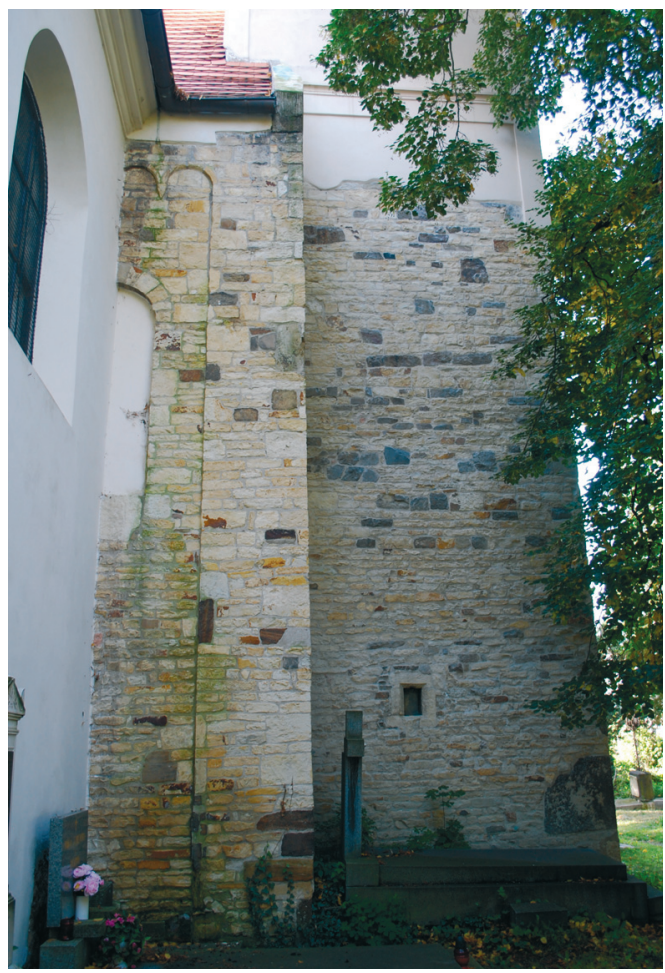

Ryc. 5. Zbraslav, Czechy. Kościół św. Gawła (fot. A. Różański)

Fig. 5. Zbraslav, Czech Republic. St. Gallus church (photo by A. Różański) 


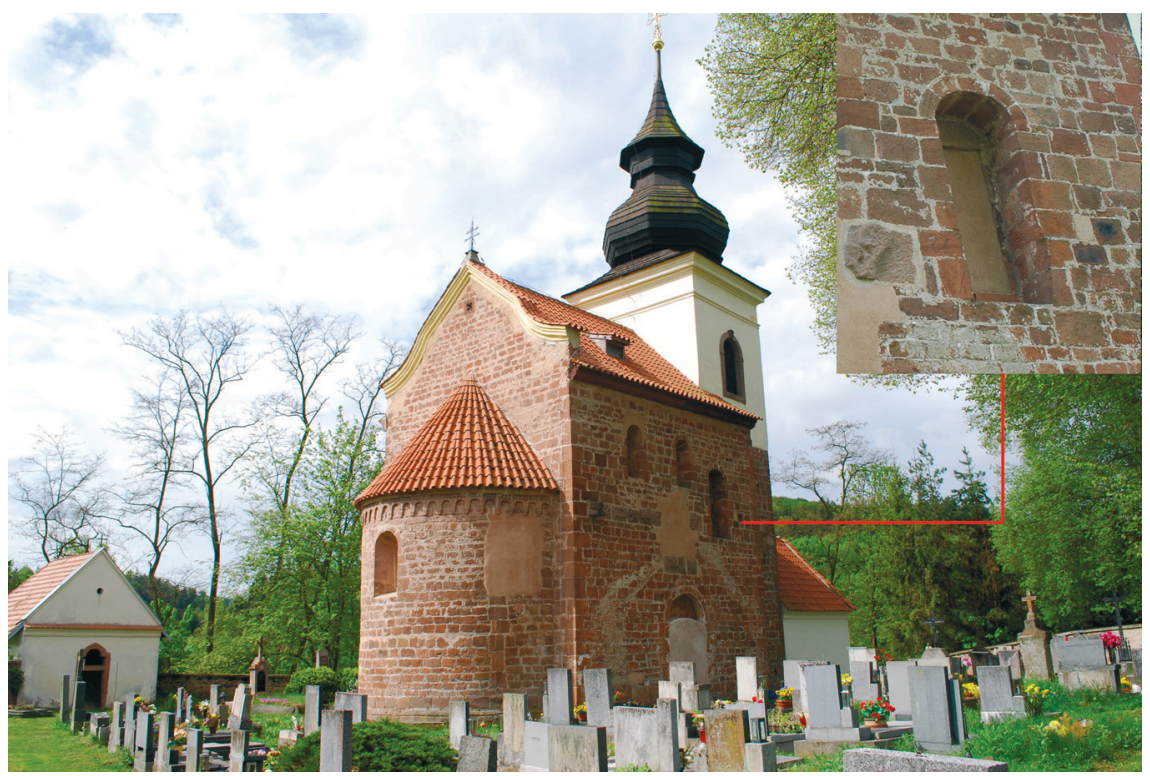

Ryc. 6. Rovná (Střibrná Skalice), Czechy. Kościół św. Jakuba (fot. A. Różański) Fig. 6. Rovná (Střibrná Skalice), Czech Republic. St. James church (photo by A. Różański)

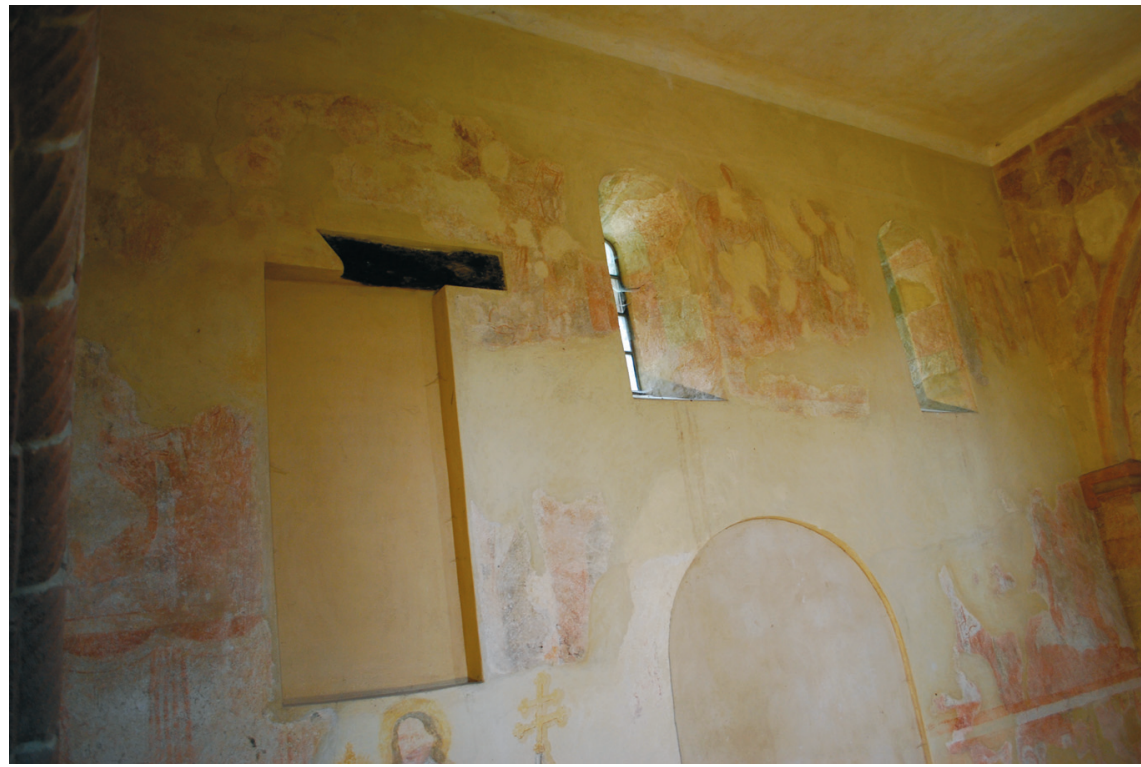

Ryc. 7. Rovná (Střibrná Skalice), Czechy. Kościół św. Jakuba - portalik od wewnątrz (fot. A. Różański)

Fig. 7. Rovná (Střibrná Skalice), Czech Republic. St. James church - small portal from inside (photo by A. Różański) 


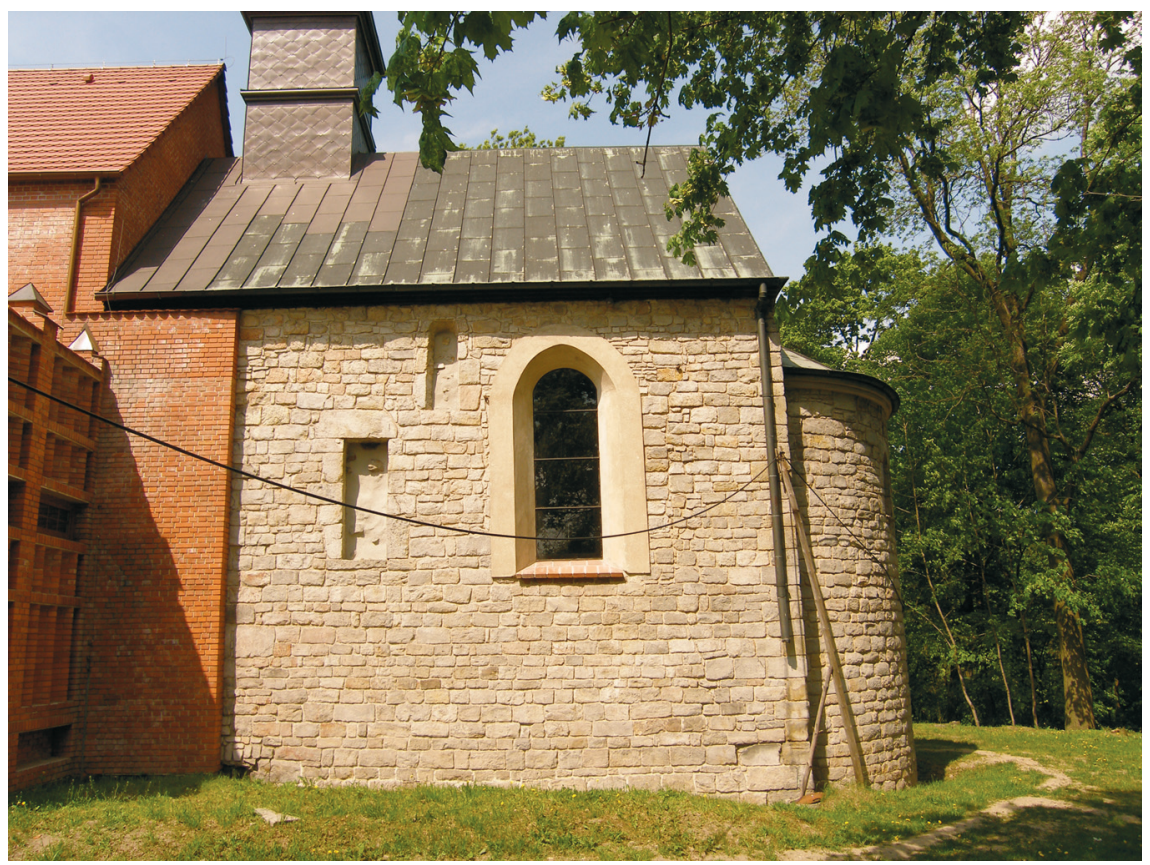

Ryc. 8. Kościelec Kolski, Polska. Kościół św. Andrzeja (fot. A. Różański)

Fig. 8. Kościelec Kolski, Poland. St. Andrew church (photo by A. Różański)

potwierdzenia w przypadku świątyni w Kościelcu. W trakcie badań archeologiczno-architektonicznych przeprowadzonych przez Andrzeja Tomaszewskiego wspólnie z Tadeuszem Poklewskim, rozpoznano teren przyległy do kościoła, zakładając wykop badawczy o wymiarach $5 \times 1,5 \mathrm{~m}$; nie stwierdzono żadnych śladów podpór, podtrzymujących przejście/mostek prowadzący do dworu (Tomaszewski 1974, s. 74-75, przypis 99). Zatem zakładaną tezę o istnieniu drewnianych ,łączników” między świątynią a dworem należy odrzucić lub też poddać dalszej weryfikacji, zwłaszcza archeologicznej. W związku z tym ciekawie przedstawia się hipoteza A. Tomaszewskiego, wskazująca przede wszystkim na refugialne funkcje empory (Tomaszewski 1974, s. 209-212). Autor prezentuje jednak swoje tezy przy założeniu, że w omawianych obiektach istniała wieża zachodnia, a tej w kościeleckiej świątyni do tej pory nie stwierdzono. Prawdopodobne jest jednak, że również w przypadku Kościelca należy wyraźnie zaakcentować funkcje obronne kościoła, tym bardziej, że w jego okolicach dotychczas nie odkryto obszaru umocnionego, odpowiadającego chronologicznie okresowi powstania obiektu sakralnego (Gorczyca 2012, s. 39).

Z przykrością trzeba zauważyć, że mimo upływu wielu lat od publikacji pracy A. Tomaszewskiego nie podjęto próby rozwiązania tego niezwykle interesującego zagadnienia, a odpowiedź na frapujące badaczy pytanie: po co rycerz-fundator kościoła miałby stawiać wieżę obronną w odległości kilku metrów od wieży kościelnej, dającej w razie zagrożenia bez wątpienia o wiele lepsze schronienie, 
do dziś nie znalazło odpowiedzi. Zatem czeską koncepcję należy uznać za błędną, nie wytrzymującą krytyki źródeł, a przede wszystkim ich braku.

$\mathrm{Na}$ koniec warto jednak zastanowić się z czym mamy do czynienia zarówno w przypadku architektury czeskiej, jak i polskiej w okresie formowania się chrześcijaństwa na naszych ziemiach. Czy formy te rzeczywiście wykazują po sobie jakiekolwiek następstwo chronologiczno-formalne? W przypadku czeskiej architektury centralnej są to: enigmatyczna rotunda p.w. św. Wita w Pradze, cztery rotundy jednoapsydowe (Levý Hradec, Budeč, Starý Plzenec, Řip), kościół Panny Marii na grodzie praskim oraz krzyżowa(?) budowla na Wyszehradzie. Kwestia recepcji formy rotundy prostej na tereny ziem polskich zza południowej granicy była już wielokrotnie omawiana w literaturze, zatem przywoływanie jej w tym miejscu jest bezzasadne. Co jakiś czas pojawiają się nowe argumenty, które w jednoznaczny sposób miałby przechylić szalę na korzyść którejś ze stron naukowego sporu. Nie tak dawno Adam Soćko w recenzji opublikowanego w 2004 roku I tomu ,Sztuki Polskiej", autorstwa Z. Świechowskiego, wskazal, że przyczyną wzniesienia około 1080-1090 roku nietypowej - jak na tereny saksońskie - rotundy prostej na zamku Groitsch w pobliżu Lipska był ślub Wiprechta von Groitzsch (†1124 rok) z siostrą króla czeskiego Wratysława II - Judytą (Soćko 2006, s. 204). Zdaniem Z. Świechowskiego jest to rezultat „transferu typu architektonicznego za sprawą przybywającej z daleka osoby fundatora czy fundatorki” czy też dalej „więzi rodzinne, sojusze polityczne wpływały w tej sytuacji szczególnie intensywnie na kierunek zapożyczenia motywów architektonicznych przenoszonych przez wędrowne zespoły" (Świechowski 2006, s. 130). Jaki zatem zestaw form prezentuje obszar, na którym zrodziło się Państwo Polskie - Wielkopolska. W świetle najnowszych badań od 2. połowy X do połowy XI wieku mamy tam do czynienia z dwiema rotundami prostymi - w Gnieźnie (Janiak 2009, s. 130-135) oraz Łeknie (Wyrwa 2004, s. 217-222); w dalszej kolejności są to skomplikowane układy przestrzenne obiektów świeckich z sakralnymi na grodach wielkopolskich (Ostrów Lednicki, Giecz). Ten niewielki katalog budowli centralnych w Wielkopolsce uzupełnia, odkryta w ostatnim czasie, kaplica palatium poznańskiego w formie kościoła krzyżowego, zamkniętego od wschodu apsydą (Kóčka-Krenz 2010, s. 221-239). Gdyby zatem hipoteza Z. Świechowskiego i A. Soćki była prawdziwa, to rotundy prostej bez wątpienia należałoby się spodziewać w Poznaniu, miejscu szczególnie do tego predestynowanym.

Podsumowując, wypada stwierdzić, że katalog form czeskich i morawskich przedstawia się zdecydowanie bardziej ubogo niż powszechnie się sądzi, zaś przyjmowane dotąd za oczywiste powiązania w świetle ponownej, krytycznej analizy wzbudzają liczne wątpliwości. Trudno przyjąć za oczywiste wskazywane przez wielu badaczy analogie między romańską architekturą czeską a polską w przypadkach, gdy podstawą ich wysnuwania nie były bezstronne badania architektoniczne (lub architektoniczno-archeologiczne), lecz raczej próby udokumentowania uprzednio sformułowanej i zaakceptowanej tezy. Oczywisty sprzeciw musi jednak budzić 
przede wszystkim naginanie faktów do jednej, z góry upatrzonej teorii. Powyższy tekst nie jest próbą podważenia dokonań tak zasłużonego badacza architektury, jakim z pewnością jest E. Małachowicz. Trudno jednak zgodzić się z faktem, że zapewne dzięki oddziaływaniu mocy autorytetu wspomnianego uczonego wątpliwe obiekty architektury monumentalnej znalazły swoje miejsce w najnowszym wydaniu „Katalogu architektury romańskiej autorstwa Z. Świechowskiego (2009)². Jednoznacznie można stwierdzić, że architektura polska w stosunku do czeskiej zwraca uwagę nie tylko większą różnorodnością układów przestrzennych i typów budowli, ale i znacznie większą ich liczbą. Tak więc, przynajmniej w zakresie architektury centralnej owe relacje między państwami Piastów a Przemyślidów nie są ani tak pewne, ani tak oczywiste, jak wydawało się jeszcze niedawno (Rodzińska-Chorąży 2000, s. 375-376). Otwarte jest więc pytanie o ich wzajemne konotacje i zależności. Pozostaje mi wyrazić nadzieję, że dalsze badania pozwolą na udzielenie odpowiedzi przynajmniej na część zasygnalizowanych w artykule wątpliwości, nie stawiając jednocześnie przed przyszłymi pokoleniami badaczy dylematów wynikających z życzeniowej interpretacji źródeł.

BIBLIOGRAFIA

Źródla

Codex - Codex diplomaticus et epistlaris Regni Bohemiae, t. 6/1, wyd. Z. Svitak, H. Krmickova, J. Krejcikova, Praha 2006.

Literatura

Benešovská K., Chotěbor P., Durdík T., Dragoun Z.

2001 Architecture of the romanesque, Praha.

Beranová M., Lutovský M.

2009 Slované v Čechách. Archeologie 6.-12. století, Praha.

Birnbaum V.

1929 Románské emporové kostely v Čechách, [w:] J. Štenc, Sbornik k sedmdesátým narozeninám Karla B. Mádla, Praha, s. 49-60.

Boháčová I.

2010 Archeologie o raně středověké architektuře ve Staré Boleslavi: hrad, kostel sv. Kosmy a Damiána, bazilika sv. Václava, kostelik sv. Klimenta a kostel neznámého (?) zasvěcení, [w:] Čechy jsou plné kostelů, Kniha k poctě $\mathrm{PhDr}$. Anežky Merhautové, red. M. Studničková, Praha, s. 190-198.

Dobosz J.

2002 Monarcha i możni wobec kościoła w Polsce do poczatku XIII wieku, Poznań.

${ }^{2}$ Chodzi o budowle pod katedrą wrocławską czy też rotundę na Gromniku. 
Dobrowolski T.

1974 Sztuka polska od czasów najdawniejszych do ostatnich, Kraków.

Firlet J., Pianowski Z.

2006 Uwagi o topografii wczesnośredniowiecznego Wawelu, Acta Archaeologica Waweliana, t. 3, s. 43-58.

Gąssowski J.

1997 Archeologia Wiślicy hipotezy i kontrowersje, [w:] Wiślica. Nowe badania

Gorczyca K.

i interpretacje, red. A. Grzybkowski, Warszawa, s. 13-19.

2012 Zarys pradziejów Koła, [w:] Najdawniejsze dzieje Koła, red. K. Gorczyca, K. Witkowski, Koło, s. 14-41.

Hołbowicz W.

1960 Z Zrac wykopaliskowych w Niemczy Śląskiej (IX-XIV w. n. ery) w roku 1960, Śląskie Sprawozdania Archeologiczne, t. 3, s. 36-40.

Janiak T.

2009 Z badań nad przestrzenia liturgiczna romańskiej katedry w Gnieźnie, [w:] Architektura romańska w Polsce. Nowe odkrycia i interpretacje, red. T. Janiak, Gniezno, s. 129-174.

Jaworski K., Pankiewicz A.

2007 Badania archeologiczne na szczycie Gromnika po II wojnie światowej, [w:] Gromnik. Z dziejów zasiedlenia i zagospodarowania szczytu, red. K. Jaworski, A. Pankiewicz, Wrocław, s. 79-122.

Kaźmierczyk J.

1991 Ku początkom Wrocławia, cz. 1, Wrocław-Warszawa.

Klápště J.

2010 Bohemia plena est ecclesiis et religione divina, [w:] Čechyjsou plné kosteli. Kniha k poctě Ph Dr. Anežky Merhautové, red. M. Studničková, Praha, s. 217-227.

Kóčka-Krenz H.

2010 Pre-romanesque Palatia Chapel in Poznań, Quaestiones Medii Aevi Novae, t. 15 , s. 221-239.

Kolář M.

1876 Památky na Plzeňsku, Památky archeologické, R. 10/2, s. 247-262.

Kurnatowska Z., Kurnatowski S.

2003 Paręuwag o odmiennościach kulturowych Małopolski (widziane od pótnocy), [w:] Polonia minor medii aevi. Studia ofiarowane Panu Profesorowi Andrzejowi Żakiemu w osiemdziesiąta rocznicę urodzin, red. Z. Woźniak, J. Garncarski, Kraków-Krosno, s. 165-178.

Małachowicz E.

2009 Wczesnośredniowieczna architektura sakralna IX-X wieku na Śląsku, [w:] Architektura romańska $w$ Polsce. Nowe odkrycia i interpretacje, red. T. Janiak, Gniezno, s. 67-94.

2010 Odkrycia architektury sakralnej z IX-Xw. na Śląsku, [w:] Čechy jsou plné kostelů. Kniha k poctě Ph Dr. Anežky Merhautové, red. M. Studničková, Praha, s. 56-68. 
Mencl V.

1937 Stredoveká architektúra na Slovensku, Praha-Prešov.

1965 Panské tribuny v naší románské architektuře, Umění, R. 13, s. 29-62. Merhautová A.

197 Raně středověká architektura v Čechách, Praha.

Merhautová A., Tř̌šstik D.

1983 Románské uměnív Čechách a na Moravě, Praha.

Miłobędzki A.

1998 Zarys dziejów architektury w Polsce, Warszawa.

Mole W.

1932/1933 Nowy pogląd na genezę rotundy św. Feliksa i Adaukta na Wawelu, Przegląd Historii Sztuki, t. 3, s. 23-30.

Nechvátal B.

1999 Radomyšl. Raně středověké pohřebiště, Praha.

Pauk M.

2000 Działalność fundacyjna możnowładztwa czeskiego i jej uwarunkowania społeczne (XI-XIII wiek), Kraków-Warszawa.

Przemyślidzi i Piastowie

2006 Przemyślidzi i Piastowie - twórcy i gospodarze średniowiecznych monarchii, red. J. Dobosz, Poznań.

Rodzińska-Chorąży T.

1998 Zespół architektoniczny na regii w Wiślicy. Próba analizy dostępnych danych, [w:] Kraje słowiańskie w wiekach średnich. Sacrum i profanum, red. H. Kóčka-Krenz, W. Łosiński, Poznań, s. 561-572.

2000 Co nam mówi architektura murowana?, [w:] Ziemie polskie $w$ X wieku i ich znaczenie w kształtowaniu sie nowej mapy Europy, red. H. Samsonowicz, Kraków, s. 361-387.

Różański A.

2009 Schody do nieba-Kościelec Kolski odkrywany na nowo, [w:] Architektura romańska w Polsce. Nowe odkrycia i interpretacje. Materiaty z sesji naukowej w Muzeum Państwa Polskiego, Gniezno, 9-11 kwietnia 2008 roku, red. T. Janiak, Gniezno, s. 525-544.

2010 Jednoprzestrzenne kościoły romańskie z terenu Wielkopolski, Poznań.

Rzeźnik P., Żurek A.

2001 Wrocław około roku 1000, [w:] Polska na przełomie I i II tysiaclecia, red. S. Skibiński, Poznań, s. 335-352.

Soćko A.

2006 (rec.) Zygmunt Świechowski (przy udziale Ewy Świechowskiej), Sztuka Polska. Romanizm, Warszawa, Arkady 2004, ss. 368, Biuletyn Historii Sztuki, t. 68, nr 2, s. 237-244.

Sommer P.

2001 Začátky křest’anstvív Čechách. Kapitoly z dějin raně středověké duchovní kultury, Praha. 
Świechowski Z

2003 Najdawniejsza architektura murowana w Polsce-jak dawna?, [w:] Polonia minor medii aevi. Studia ofiarowane Panu Profesorowi Andrzejowi Żakiemu w osiemdziesiątą rocznicę urodzin, red. Z. Woźniak, J. Garncarski, KrakówKrosno, s. 133-161.

2006 Relikty średniowiecznych budowli opactwa w Łeknie ważne z uwagi na kontekst, Studia i Materiały do Dziejów Pałuk, t. 6, s. 127-138.

2009 Katalog architektury romańskiej $w$ Polsce, Warszawa.

Tomaszewski A.

1974 Romańskie kościoły z emporami zachodnimi na obszarze Polski, Czech $i$ Wegier, Wrocław.

1997 Badania wiślickie między przeszłościa a przyszłościa, [w:] Wiślica. Nowe badania i interpretacje, red. A. Grzybkowski, Warszawa, s. VIII.

Wyrozumski J.

2006 Kraków w chrześcijańskiej Europie X-XIII w., [w:] Kraków w chrześcijańskiej Europie X-XIII w. Katalog wystawy, Kraków, s. 37-77.

Wyrwa A. M.

2004 Monumentalna i drewniana architektura sakralna $w$ tekneńskim kompleksie osadniczym do końca XIII wieku, [w:] Poczatki architektury monumentalnej w Polsce, red. T. Janiak, D. Stryjniak, Gniezno, s. 213-243.

CZECH AND MORAVISN ARCHITECTONIC PATTERNS

IN THE AREA OF POLISH GROUNDS

IN EARLY MIDDLE AGES. FACTS AND MYTHS

Summary

Since the beginning of $20^{\text {th }}$ century there has been a deep conviction existing amongst archaeologists, historians and art historians concerning inseparable connections of Polish oldest pre-Romanesque and Romanesque buildings with Czech and Moravian architecture. Indicating a number of obvious, as they seem, analogies and implementing existing written sources, southern inspirations of Polish builders of early Middle Ages are regarded as a fact. However, secondary, even fragmentary analysis of construction available today and their relics make us doubt in incontrovertible existence of dependences between the objects under discussion, at least as far as central architecture is concerned. Connoting, e.g. instances of churches in Wrocław, Niemcza or in Gromnik, as well as examples of lay monumental architecture (or rather their relics) i would like to signal the necessity of considering the problem of formal dependences common for the objects in discussion once again and in consequence also Premyslid and Piasts architecture of early Middle Ages period. The article purpose is not to present new conception concerning origin of the oldest Polish mortared objects, but subjecting the problem to critic and reflection on the statements obligatory so far, which have not always been based on undisputed source arguments. The problem requires further research and the text above can be regarded only as a starting point to it. 
